Saudi Journal of Economics and Finance

Abbreviated Key Title: Saudi J Econ Fin ISSN 2523-9414 (Print) |ISSN 2523-6563 (Online) Scholars Middle East Publishers, Dubai, United Arab Emirates Journal homepage: http://saudijournals.com/sjef/

\title{
The Effect of IFRS Adoption, Information Asymmetry and Deferred Tax Assets on Earning Management
}

Ami Jayanti', Apollo

Universitas Mercu Buana, J1. Meruya Selatan No.1, RT.4/RW.1, Meruya Sel., Kec. Kembangan, Kota Jakarta Barat, Daerah Khusus Ibukota Jakarta 11650, Indonesia

DOI: $10.36348 /$ SJEF.2019.v03i09.010

| Received: 10.09.2019| Accepted: 17.09.2019| Published: 30.09.2019

*Corresponding author: Ami Jayanti

Abstract

This research aims to effect of ifrs adoption, Information Asymmetry and Deferred Tax Assets to Earnings Management. The measurement of earnings management used in this research with an approach discretionary accruals modified model jones [1]. This research is included in descriptive research. The population of this research is various industrial manufacturing companies listed on the Stock Exchange in 2013-2017. The sample obtained was 120 sample using purposive sampling technique. In analyzing the data used a quantitative approach through Software Eviews 8. The simultaneous IFRS Adoption, Information Asymmetry and Deferred Tax Assets have a significant effect on Earnings Management. Partially, IFRS Adoption has no significant effect on Earnings Management, Information Asymmetry has a significant effect on earnings management, and Deferred Tax assets have a significant effect on Earnings Management Keyword: Earnings management, IFRS adoption, Information Asymmetry, Deferred tax assets.

Copyright @ 2019: This is an open-access article distributed under the terms of the Creative Commons Attribution license which permits unrestricted use, distribution, and reproduction in any medium for non-commercial use (NonCommercial, or CC-BY-NC) provided the original author and source are credited.

\section{INTRODUCTION}

One form of management accountability for the company's stakeholders is reflected in the financial statements [2]. The purpose of financial statements is to provide information about financial position, financial performance, and entity cash flows that benefit most users of financial statements in making economic decisions.

One of the most important information is profit information. Scott [2] states that profits are important and needed by users in a broad scope as a summary of measuring company performance such as compensation programs, debt agreements, companies that will go public, investors and creditors. In financial statements, profit is information that becomes a benchmark for the company's operational performance, therefore management does various ways, one of which is to implement earnings management. Phenomena that often occur in relation to earnings management usually arise due to the form of errors and omissions from the subject of financial management itself which are directly or indirectly influenced by various factors, both internal and external. For example, one of the recent cases of earnings management is an accounting scandal by Toshiba. According to an independent committee, the company inflated very high operating profits.
The formulation of the problem in this study is whether ifrs adoption, information asymmetry and deferred tax assets affect earnings management.

\section{DESIGN AND METHOD}

This research belongs to descriptive research. The population of this study is various industrial manufacturing companies listed on the Indonesia Stock Exchange which published financial statements for 2013-2017. The sample in this study used a purposive sampling method. This research method uses quantitative methods.

Data processing using Eviews version 8. The analysis methods in this study include:

- Test- $t$ (Partial Test)

- $\quad$ Test-F (Simultaneous Test)

- Determination Coefficient Test $\left(\mathrm{R}^{2}\right)$

Regression analysis was performed using a panel data regression analysis method with the following equation model:

$$
\begin{aligned}
& Y=\beta \mathrm{o}+\beta_{1} X_{1}+\beta_{2} X_{2}+\beta_{3} X_{3}+\varepsilon \\
& Y=-0,009+0,120+0,002-0,048+\varepsilon
\end{aligned}
$$




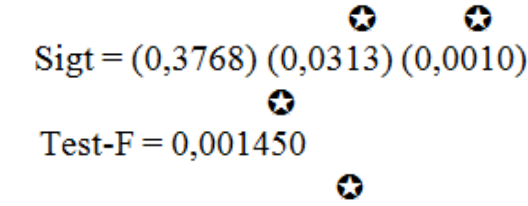

Adjt R Square=0,101778@R=10.1778\%

$\alpha=0,05$

$\boldsymbol{\theta}=$ significant

$\mathrm{n}=120$ sampling

$\mathrm{Y}=$ Earnings management

$\mathrm{X}_{1}=$ IFRS adoption

$\mathrm{X}_{2}=$ Information asymmetry

$\mathrm{X}_{3}=$ Deferred tax assets

$\beta \mathrm{o}=$ Constant

$\beta_{1} \beta_{2} \beta_{3}=$ Coefficient

$\varepsilon=$ Error Term $(89.8222 \%)$

\section{RESULTS AND DISCUSSION}

\section{Test- t (Partial Test)}

Based on the results of the equation above, the results are obtained that partially IFRS adoption has no significant effect on earnings management while the information asymmetry and deferred tax assets have a significant effect on earnings management in each of the sample companies in 2013-2017.

\section{Test-F (Simultaneous Test)}

Based on the results of the equation above, the estimation results produce Prob (F Statistics) of 0.001450 . Value Using $\alpha=0.05$ indicates that IFRS Adoption, Information Asymmetry, and Deferred Tax Assets simultaneously or jointly have a significant effect on Earnings Management $(0.001450<0.05)$. Based on the hypothesis proposed reject Ho, which means statistically IFRS Adoption, Information Asymmetry, and Deferred Tax Assets simultaneously or jointly significantly influence the Profit Management ( $\alpha$ $=0.05$ ).

\section{Determination Coefficient Test (R2)}

Based on the results of the equation above, the results of the coefficient of determination that is equal to 0.101778 or equal to $10.1778 \%$. This means that the contribution of IFRS Adoption, Information Asymmetry and Deferred Tax Assets contribution to earnings management is $10.1778 \%$. While the remaining $89.8222 \%$ is contributed by other variables not discussed in this study.

Hypothesis testing has been carried out, it can be put forward some discussion below:

\section{IFRS adoption has no significant effect on earnings management}

The results of this study are consistent with the results of previous studies conducted by Manzano and Conesa [3], that the results do not provide evidence for the effect of IFRS adaptation in reducing earnings management.

\section{Information asymmetry has a significant effect on earnings management}

The results of this study are consistent with the results of previous studies conducted by Yustiningarti and Asyk [4], namely information asymmetry has a significant positive effect on earnings management.

\section{Deferred tax assets have a significant effect on earnings management}

The results of this study are consistent with the results of previous studies conducted by Timuriana and Muhamad [5], namely deferred tax assets have an influence on earnings management

\section{CONCLUSIONS AND SUGGESTIONS CONCLUSIONS}

Based on the results of research with panel data regression analysis, the conclusions of this study are:

- The adoption of IFSR has no significant effect on earnings management. IFRS is not necessarily fully compatible if implemented in countries with different characteristics. Differences in the characteristics of a company or country in general can also make the adoption of IFRS not effective. The state of the form of the company, the shape of the country, economic conditions and market developments can be other considerations.

- Information asymmetry has a significant effect on earnings management. When information asymmetry occurs, shareholders do not have sufficient resources or access to relevant information to monitor the actions of managers, which will provide managers with opportunities to manage earnings.

- Deferred tax assets have a significant effect on earnings management. When deferred tax assets are increasingly high, it indicates that the company will increase earnings management actions.

\section{SUGGESTIONS}

In this study there are still some deficiency, and I suggest:

- For further research, earnings management in this study uses discretionary accruals modified jones model [1]. The researcher can then use alternative models and add other variables with different sectors and a greater amount of data to provide better results.

- For stakeholders, before investing in a company, investors must be careful in seeing the accrual information presented in the company's financial statements related to earnings management practices in order to reduce the risk of loss that will be borne by investors.

- For companies, the Company is obliged to publish financial statements regularly to provide information needed for users of financial statements, financial statements that are published 
and are expected to continue to run within the limits of generally accepted accounting standards and do not take earnings management actions.

\section{REFERENCES}

1. Assal, M, Mamdouh EL . (2012). The Effect of the Recognition for the Deferred Tax Assets on Earnings Management. A Thesis Cairo University Faculty of Commerce Accounting Department.

2. Apollo, (2003). Beberapa Faktor Yang Mempengaruhi Earningss Management Serta Penerapannya Dalam Penyusunan Laporan Keuangan. (Disertasi). Universitas Padjadjaran, Bandung.

3. Apollo, (2017). Pembuatan Diskursus Teori Akuntansi Konflik Keagenan (Agency Theory), Studi Etnografi Reinterprestasi Hermeneutika Candi Sukuh, Ceto Jawa Tengah. ID Patent C00,201,703,561, | vol: | issue : | 2017

4. Besten, Priscilla Samantha, Georgios Georgakopoulos, Konstantinos Z. Vasileiou dan Nikolas Ereiotis. 2015. The Impact of IFRS Adoption onEarning Quality: A Study Conducted on Foreign Issuers in the United States. International Business Research. Vol. 8 No. 11.

5. Dai, Yunhao, Dongmin Kong, dan Li Wang. 2013. Information asymmetry, mutual funds and earnings management: Evidence from China. China Journal of Accounting Research 6 (2013) 187- 209.

6. Dechow, Patricia M, Richard G. Sloan, and Amy P. Sweeney. 1995. Detecting Earnings Management. The Accounting Review, 70(2).

7. Daniel Zeghal, Sonda M. Chtourou, and Yosra M. Fourati. 2012. The Effect of Mandatory Adoption of IFRS on Earnings Quality: Evidence from the European Union. Journal of International Accounting Research Volume 11, No. 2.

8. Fitriany, Lusi Citra. 2016. Pengaruh Aset Pajak Tangguhan, beban Pajak Tangguhan dan Perencanaan Pajak Terhadap Manajemen Laba. JOM Fekon Vol. 3. No.1.

9. Harnovinsah, 2015. The Market Reaction and Income Smoothing (Case Study on Listed Company in LQ 45 Indonesian Stock Exchange). Research Journal of Finance and Accounting ISSN 2222- 1697 (Paper) ISSN 2222-2847 (Online) Vol.6, No.8, 2015.

10. Lasdi, Lodovicus 2013.. The Effect of Informations Asymmetry on Earning Management Through Accrual and Real Activity During Global Financial Crisis. Journal of Economics, Business and
Accounting. Vol 16 No.2.Note and Extention. Journal of Business Finance \& Accounting.

11. Mita, A. F. (2015). Pengaruh langsung tingkat adopsi IFRS terhadap home country bias dan pengaruh tidak langsungnya melalui daya banding laporan keuangan. (Disertasi). Universitas Indonesia, Indonesia, Depok.

12. Nengzih, 2015. The Adoption of IFRS - Impact on Profitability Rate and Tax Income: Evidence from Companies Indonesia Listed in Indonesian Stock Exhange. Research Journal of Finance and Accounting ISSN 2222- 1697 (Paper) ISSN 22222847 (Online) Vol.6, No.11, 2015.

13. Palacios, Manzano dan M. Martinez Conesa. 2014. Assesing the Impact of IFRS Adaption on Earnings Management: An Emerging Market Perspective. Transformations in Business dan Economics. Vol. 13. No. 1 (31) pp. 21-40.

14. Ratna, dkk. 2016, The Impact of Free Cash Flow and Good Corporate Governance (GCG) Earning Management of the Banking Companies Listed on the Indonesia Stock Exchange. ISSN 2222-1697 (Paper) ISSN 2222-2847 (Online) Vol.7, No.20, 2016.

15. Scott, W. R. 2015. Financial Accounting Theory. USA: Prentice Hall.

16. Tang, T. 2006. Book-Tax Differences: a Function of Accounting-Tax Misalignment, earnings Management and Tax Management: Empirical Evidence From China. Paper Presented at 2006 AAA Annual Meeting, American Accounting Association Annual Meeting, Washington, DC, USA.

17. Wiyadi, Andri Veno dan Noer Sasongko. 2015. Information Asymmetry and Earning Management: Good Corporate Governance as Moderating Variable. South East Asia Journal of Contemporary Business, Economics and Law. Vol. 7. Issue 2.

18. Wiyadi, Rina Trisnawati, Noer Sasongko dan Ichwan Fauzi. 2015. The Effect of Information Asymmetry, Firm Size, Leverage, Profitability and Employee Stock Ownership on Earnings Management with Acrual Model. International Journal of Business, Economics and Law. Vol. 8. Issue 2.

19. Waluyo. 2014. Akuntansi Pajak. Jakarta: Salemba Empat.

20. Yoga Sukmana. 2015. Bos Toshiba Dilaporkan Terlibat Skandal Penyimpangan Akuntansi. Kompas.com. Diakses: 26 Mei 2017. 